\title{
Case-control study of diarrheal disease etiology in individuals over 5 years in southwest China
}

Shun-Xian Zhang ${ }^{1,2+}$, Chun-Li Yang ${ }^{1,2+}$, Wen-Peng Gu ${ }^{3 \dagger}$, Lin Ai ${ }^{1,2}$, Emmanuel Serrano ${ }^{4,5}$, Pin Yang ${ }^{1,2}$, Xia Zhou ${ }^{6}$, Shi-Zhu Li, ${ }^{1,2}$, Shan Lv1,2, Zhi-Sheng Dang 1,2, Jun-Hu Chen ${ }^{1,2}$, Wei Hu ${ }^{1,2}$, Li-Guang Tian ${ }^{1,2}$, Jia-Xu Chen ${ }^{1,2^{*} \neq}$ and Xiao-Nong Zhou ${ }^{1,2^{*} \neq}$

\begin{abstract}
Background: Acute diarrhea is one of the major public health problems worldwide. Most of studies on acute diarrhea have been made on infants aged below 5 years and few efforts have been made to identify the etiological agents of acute diarrhea in people over five, especially in China.

Methods: 271 diarrhea cases and 149 healthy controls over 5 years were recruited from four participating hospitals between June 2014 and July 2015. Each stool specimen was collected to detect a series of enteric pathogens, involving five viruses (Rotavirus group A, RVA; Norovirus, NoV; Sapovirus, SaV; Astrovirus, As; and Adenovirus, Ad), seven bacteria (diarrheagenic Escherichia coli, DEC; non-typhoidal Salmonella, NTS; Shigella spp.; Vibrio cholera; Vibrio parahaemolyticus; Aeromonas spp.; and Plesiomonas spp.) and three protozoa (Cryptosporidium spp., Giardia lamblia, G. lamblia, and Blastocystis hominis, B. hominis). Standard microbiological and molecular methods were applied to detect these pathogens. Data was analyzed using Chi square, Fisher-exact tests and logistic regressions.

Results: The prevalence of at least one enteric pathogen was detected in 29.2\% (79/271) acute diarrhea cases and in $12.1 \%(18 / 149)$ in healthy controls $(p<0.0001)$. Enteric viral infections $(14.4 \%)$ were the most common in patients suffering from acute diarrhea, followed by bacteria (13.7\%) and intestinal protozoa (4.8\%). DEC (12.5\%) was the most common causative agent in diarrhea cases, followed by NoV GII (10.0\%), RVA (7.4\%) and B. hominis (4.8\%). The prevalence of co-infection was statistically higher $(p=0.0059)$ in the case group $(7.7 \%)$ than in the healthy control $(1.3 \%)$. RVA-NoV GII (3.0\%) was the most common co-infection in symptomatic cases.

Conclusions: DEC was the most predominant pathogen in diarrhea cases, but it was largely overlooked because the lack of laboratory capacities. Because of the high prevalence of co-infections, it is recommended the urgent development of alternative laboratory methods to assess polymicrobial infections. Such methodological improvements will result in a better prevention and treatment strategies to control diarrhea illness in China.
\end{abstract}

Keywords: Acute diarrhea, Bacteria, Virus, Enteric protozoa, Co-infection

\footnotetext{
*Correspondence: chenjiaxu1962@163.com; ipdzhouxn@sh163.net

tShun-Xian Zhang, Chun-Li Yang and Wen-Peng Gu contributed equally to this manuscript

${ }^{\ddagger}$ Jia-Xu Chen and Xiao-Nong Zhou contributed equally to this manuscript

${ }^{1}$ National Institute of Parasitic Diseases, Chinese Center for Disease

Control and Prevention, Shanghai 200025, People's Republic of China

Full list of author information is available at the end of the article
} 


\section{Background}

Diarrheal illness is still a serious public health problem that particularly affects individuals in middle and low income countries [1]. Diarrhea is still a major reason of attendance at health services and one of the general causes for hospital admission [2]. In addition, 1,400,000 million deaths are caused by diarrhea across all age groups, of which 700,000 deaths are over 5 years $[1,2]$.

The main enteric pathogens include a wide range of bacteria (e.g. diarrheagenic Escherichia coli, DEC; nontyphoidal Salmonella, NTS; Shigella spp.; Vibrio cholera; Vibrio parahaemolyticus; Aeromonas spp.; Plesiomonas spp.; Campylobacter spp.), virus (e.g. rotavirus group A, RVA; norovirus, NoV; Sapovirus, SaV; astrovirus, As; adenovirus, Ad; enterovirus.) and enteric parasites (e.g. Cryptosporidium spp.; Giardia lamblia, G. lamblia; Entamoeba histolytica and Blastocystis hominis, B. hominis) [3-8].

Most researches of enteric pathogens on individuals with and without diarrhea have been largely based on a single or few pathogen species [9-11]. However, coinfection is a common prevalence in diarrhea cases in such communities with poor food hygiene, low sanitation and contaminated water (35.0, 20.1, 13.0\%, respectively) $[6,12,13]$. Co-infection, however, are also common in healthy patients $(8.0,5.3,0.8 \%$, respectively) $[6,12,13]$. Co-infection is of particular human health importance because pathogen species can interact within the host. Interactions within the host can have either positive or negative effects on each of the co-infecting enteric pathogen species. Under positive enteric pathogen interactions, diarrheal disease transmission and progression are enhanced $[6,12,14,15]$.

Infectious diarrhea is still one of the important public health problems in China. The reported infectious diarrhea is up to 70,000,000, and the reported incidence of infectious diarrhea is 55.9/10,000,000 annually in China listed by China Information System for Diseases Control and Prevention. Diarrheal illness incidence is located in top three of 39 notifiable infectious diseases $[11,16]$. However, in many medical institutions, the lack of clinical microbiology laboratories and detection capabilities hamper the detection of etiological agents of gastroenteritis. As result, etiology of gastroenteritis in China is achieved in less than $5.0 \%$ of patients [11]. In addition, most of the diarrhea studies have been limited to children under 5 years and either bacterial or viral species $[11,17,18]$. Hence, the aim of the study was twofold: one was to investigate the etiology of diarrhea cases in people over 5 years and to assess patterns of co-infection among virus, bacteria and protozoa in patients from southwest China. This study will contribute to the effective control of acute diarrhea in the country.

\section{Methods}

\section{Subjects of this study}

Acute gastroenteritis patients were defined as those who had diarrhea over three times within $24 \mathrm{~h}$ with abnormal stool specimens (e.g. mucus stool, watery stool, loose stool or bloody stool) in accordance with the WHO standard [19]. Non-diarrheal subjects were defined as those who had no history of diarrhea symptom before 14 days and were recruited at the same time as diarrheal subjects.

\section{Specimen and data collection}

The stool specimens were collected from acute diarrhea cases and healthy controls over 5 years in outpatient from four sentinel hospitals as follows: The First people's Hospital of Yunnan Province, Kunming Children's Hospital, The Pushan Community Health Service Center in Kunming, The First People's Hospital of Yunnan Province, and The First Affiliated Hospital of Kunming Medical University. A sterile sampling cup was applied to collect stool sample, with the criterion that each stool must be greater than $3 \mathrm{~g}$ or $3 \mathrm{~mL}$, then each stool specimen was delivered to the laboratory of Yunnan Provincial Center for Disease Control and Prevention in Cary-Blair (C-B) culture medium (Oxoid Ltd, Basingstoke, UK) within $12 \mathrm{~h}$. The clinical (e.g. fever, abdominal pain, nausea, vomiting, dehydration and tenesmus) and basic epidemiological data (e.g. sex, age, residence and season) was collected with structured questionnaire by doctors or nurses. The present study was conducted from July 2014 to June 2015.

\section{Laboratory test for enteric pathogens}

Each stool sample was divided into three aliquots (Additional file 1). The first one was used for isolating, culturing and identifying bacterial (DEC, NTS, Shigella spp., Vibrio cholera, Vibrio parahaemolyticus, Aeromonas spp. and Plesiomonas spp.), the second one detect viral pathogens (RVA; NoV; astrovirus As, and Adenovirus, Ad), and last to assess intestinal protozoa infection (Cryptosporidium spp., G. lamblia and B. hominis).

\section{Bacterial detection}

MacConkey agar (MAC, Oxoid Ltd, Basingstoke, UK) was used for culturing DEC, which was divided into five subtypes by their virulence genetic as following: enteroaggregative $E$. coli (EAEC), enterotoxigenic $E$. coli (ETEC), enteropathogenic E. coli (EPEC), enteroinvasive E. coli (EIEC) and enterohaemorrhagic E. coli (EHEC). The DEC subtypes were examined with quantitative PCR based on the previous literatures (Table 1) $[20,21]$. Each stool sample was inoculated into the selenite brilliant green sulfa enrichment broth (Oxoid Ltd, Basingstoke, UK) for enrichment and then inoculated 
Table 1 The primers and reactions condition applied to detect enteric pathogens in this study

\begin{tabular}{|c|c|c|c|c|c|}
\hline Enteric pathogens & Target gene & Primer $\left(5^{\prime}-3^{\prime}\right)$ & Amplicon sizes (bp) & Remarks & Source \\
\hline EPEC & eae & CCACGGTTTATCAAACTGATAACG & 105 & \multirow{11}{*}{$\begin{array}{l}\text { Each stool specimen was inoculated to MAC } \\
\text { media to culture DEC at } 37^{\circ} \mathrm{C} \text { for } 18 \mathrm{~h} \text {, And } \\
\text { then ten putative DEC colonies were selected } \\
\text { to mix with } 150 \mu \mathrm{L} \text { water to extract DNA } \\
\text { at } 100^{\circ} \mathrm{C} \text { for } 10 \mathrm{~min} \text {, and then the } 20 \mu \mathrm{L} \\
\text { volume of qPCR system is composed of } 10 \mu \mathrm{L} \\
\text { master mix (Takara Bio Inc, Shiga, Japan), } 1 \mu \mathrm{L} \\
\text { forward primer ( } 10 \mu \mathrm{mol}), 1 \mu \mathrm{L} \text { reverse primer } \\
(10 \mu \mathrm{mol}), 1 \mu \mathrm{L} \text { DNA template and } 7 \mu \mathrm{L} \mathrm{H}_{2} \mathrm{O} \text {. } \\
\text { The cycling conditions for each subtype DEC } \\
\text { was } 95^{\circ} \mathrm{C} \text { for } 5 \text { min, } 40 \text { cycles of } 95^{\circ} \mathrm{C} \text { for } 5 \mathrm{~s} \text {, } \\
60^{\circ} \mathrm{C} \text { for } 30 \mathrm{~s} \text {. The fluorescence recorded was } \\
\text { at the annealing stage }\end{array}$} & \multirow[t]{15}{*}[20,21]{} \\
\hline \multirow[t]{4}{*}{ EHEC } & \multirow[t]{2}{*}{ stx1 } & ACTTCTCGACTGCAAAGACGTATG & \multirow[t]{2}{*}{132} & & \\
\hline & & ACAAATTATCCCCTGAGCCACTATC & & & \\
\hline & \multirow[t]{2}{*}{$s t \times 2$} & CCACATCGGTGTCTGTTATTAACC & \multirow[t]{2}{*}{93} & & \\
\hline & & GGTCAAAACGCGCCTGATAG & & & \\
\hline \multirow[t]{6}{*}{ ETEC } & \multirow[t]{2}{*}{ elt } & TTCCCACCGGATCACCAA & \multirow[t]{2}{*}{62} & & \\
\hline & & CAACCTTGTGGTGCATGATGA & & & \\
\hline & \multirow[t]{2}{*}{ estA } & CCTTTCGCTCAGGATGCTAAAC & \multirow[t]{2}{*}{128} & & \\
\hline & & CAGTAATTGCTACTATTCATGCTTTCAG & & & \\
\hline & \multirow[t]{2}{*}{ estB } & CTTTCCCCTCTTTTAGTCAGTCAACT & \multirow[t]{2}{*}{137} & & \\
\hline & & GCAGTAAAATGTGTTGTTCATATTTTCTG & & & \\
\hline \multirow[t]{2}{*}{ EAEC } & \multirow[t]{2}{*}{$\operatorname{aggR}$} & CAGCGATACATTAAGACGCCTAAAG & \multirow[t]{2}{*}{116} & & \\
\hline & & CGTCAGCATCAGCTACAATTATTCC & & & \\
\hline \multirow[t]{2}{*}{ EIEC } & \multirow[t]{2}{*}{$\mathrm{ipaH}$} & ACCATGCTCGCAGAGAAACT & \multirow[t]{2}{*}{175} & & \\
\hline & & TCAGTACAGCATGCCATGGT & & & \\
\hline \multirow[t]{2}{*}{ RVA } & \multirow[t]{2}{*}{ VP6 } & GACGGVGCRACTACATGGT & \multirow[t]{2}{*}{382} & \multirow{10}{*}{$\begin{array}{l}\text { RVA, NoV Gl, NoV Gll, SaV and As were RNA } \\
\text { viruses, complementary DNA (CDNA) was } \\
\text { synthesized using a random primer (Takara Bio } \\
\text { Inc, Shiga, Japan) at } 55^{\circ} \mathrm{C} \text { for } 1.5 \text { h, followed } \\
\text { by } 100^{\circ} \mathrm{C} \text { for } 10 \text { min, and holding at } 4{ }^{\circ} \mathrm{C} \text {. } \\
\text { The reaction condition of RVA was } 94^{\circ} \mathrm{C} \text { for } \\
5 \text { min, followed by } 40 \text { cycles at } 94^{\circ} \mathrm{C} \text { for } 1 \text { min, } \\
42^{\circ} \mathrm{C} \text { for } 1 \text { min, } 72^{\circ} \mathrm{C} \text { for } 1 \text { min, and with final } \\
\text { extension at } 72{ }^{\circ} \mathrm{C} \text { for } 10 \text { min. Multiplex RT-PCR } \\
\text { was used to detect the presence of NoV Gl, } \\
\text { NoV Gll, and SaV, the thermal profile consisted } \\
\text { of } 94^{\circ} \mathrm{C} \text { for } 5 \text { min, } 40 \text { cycles of } 94^{\circ} \mathrm{C} \text { for } 70 \mathrm{~s} \text {, } \\
49^{\circ} \mathrm{C} \text { for } 70 \mathrm{~s} \text {, and } 72{ }^{\circ} \mathrm{C} \text { for } 1 \text { min, followed } \\
\text { by } 72{ }^{\circ} \mathrm{C} \text { for } 10 \text { min. The thermal profile of As } \\
\text { was } 94{ }^{\circ} \mathrm{C} \text { for } 5 \text { min, } 40 \text { cycles of } 94^{\circ} \mathrm{C} \text { for } 30 \mathrm{~s} \text {, } \\
55^{\circ} \mathrm{C} \text { for } 30 \mathrm{~s} \text {, and } 72{ }^{\circ} \mathrm{C} \text { for } 1 \text { min, followed by } \\
72^{\circ} \mathrm{C} \text { for } 10 \text { min }\end{array}$} & \multirow[t]{2}{*}[22]{} \\
\hline & & GTCCAATTCATNCCTGGTGG & & & \\
\hline \multirow{6}{*}{$\begin{array}{l}\text { NoV Gl } \\
\text { NoV Gll } \\
\text { SaV }\end{array}$} & \multirow[t]{6}{*}{ Polymerase } & TGACGATTTCATCATCACCATA & $331 / 319$ & & {$[23]$} \\
\hline & & TGACGATTTCATCATCCCCGTA & & & \\
\hline & & GATTACTCCAGGTGGGACTCCAC & & & \\
\hline & & GATTACTCCAGGTGGGACTCAAC & & & \\
\hline & & GATTACTCCAGGTGGGATTCAAC & & & \\
\hline & & GATTACTCCAGGTGGGATTCCAC & & & \\
\hline As & Capsid & CAACTCAGGAAACAGGGTGT & 449 & & {$[24]$} \\
\hline & & TCAGATGCATTGTCATTGGT & & & \\
\hline Ad & Hexon & TTCCCCATGGCICAYAACAC & 482 & The thermal profile was $94^{\circ} \mathrm{C}$ for 5 min, 40 cycles & {$[25]$} \\
\hline & & CCCTGGTAKCCRATRTTGTA & & $\begin{array}{l}\text { of } 94^{\circ} \mathrm{C} \text { for } 30 \mathrm{~s}, 55^{\circ} \mathrm{C} \text { for } 30 \mathrm{~s} \text {, and } 72^{\circ} \mathrm{C} \text { for } \\
1 \mathrm{~min} \text {, followed by } 72^{\circ} \mathrm{C} \text { for } 10 \mathrm{~min}\end{array}$ & \\
\hline Blastocistis hominis & SSU-rRNA & CGAATGGCTCATTATATCAGTT & 260 & The thermal profile was $94^{\circ} \mathrm{C}$ for $5 \mathrm{~min}, 40$ cycles & {$[26]$} \\
\hline & & TCTTCGTTACCCGTTACTGC & & $\begin{array}{l}\text { of } 94^{\circ} \mathrm{C} \text { for } 30 \mathrm{~s}, 53^{\circ} \mathrm{C} \text { for } 30 \mathrm{~s} \text {, and } 72^{\circ} \mathrm{C} \text { for } \\
1 \mathrm{~min} \text {, followed by } 72^{\circ} \mathrm{C} \text { for } 10 \mathrm{~min}\end{array}$ & \\
\hline Cryptosporidium spp. & 18S-rRNA & TTCTAGAGCTAATACATGCG & & The primary cycle consisted of $94^{\circ} \mathrm{C}$ for $5 \mathrm{~min}$, & {$[27]$} \\
\hline & & CCCATTTCCTTCGAAACAGGA & & 35 cycles of $94^{\circ} \mathrm{C}$ for $50 \mathrm{~s}, 55^{\circ} \mathrm{C}$ for $1 \mathrm{~min}$ and & \\
\hline & & GGAAGGGTTGTATTTATTAGATAAAG & 840 & annealing step for a second reaction was $58^{\circ} \mathrm{C}$ & \\
\hline & & CTCATAAGGTGCTGAAGGAGTA & & & \\
\hline Giardia lamblia & Tim & AAATIATGCCTGCTCGTCG & & The thermal profile of first round was $94^{\circ} \mathrm{C}$ for & {$[28]$} \\
\hline & & CAAACCTTITCCGCAAACC & & $1 \mathrm{~min}, 53^{\circ} \mathrm{C}$ for $1 \mathrm{~min}$, and $72^{\circ} \mathrm{C}$ for $1 \mathrm{~min}$, fol- & \\
\hline & & CCCTTCATCGGIGGTAACTT & 530 & was carried out similarly & \\
\hline & & GTGGCCACCACICCCGTGCC & & & \\
\hline
\end{tabular}

DEC is composed of EAEC, EPEC, EIEC, ETEC and EHEC in this study, the judging standard of subtypes of DEC according to qPCR was: EPEC: eae+; EAEC: aggR+; EIEC: $\mathrm{ipaH}+$; EHEC: eae+, and (stx1+; and/or stx2+); ETEC: hlt+, and/or estA, and/or estB+

it onto Salmonella-Shigella agar (Oxoid Ltd, Basingstoke, UK) to detect NTS. In addition, each stool specimen was inoculated directly onto Salmonella-Shigella agar (Oxoid Ltd, Basingstoke, UK) to find Shigella spp. Moreover, each sample was inoculated onto alkaline peptone water (Oxoid Ltd, Basingstoke, UK) for enrichment, and then inoculated onto thiosulfate-citrate-bile salts-sucrose agar (Oxoid Ltd, Basingstoke, UK) to detect
Vibrio cholera, Vibrio parahaemolyticus, Aeromonas spp. and Plesiomonas spp. For suspicious NTS, Shigella spp., Vibrio cholera, Vibrio parahaemolyticus, Aeromonas spp., and Plesiomonas spp. colonies. The systematic biochemical identification of was performed using the VITEK ${ }^{\circledR}$ 2 Compact instrument (bioMerieux, Marcyl'Etoile, France). Detailed detection procedures are found in references $[11,17]$. 


\section{Virus detection}

Nucleic Acid was extracted from each stool specimen (15\% wt/vol or vol/vol suspension) with QIAamp Viral RNA Kit (Qiagen, Hilden, Germany). The reverse transcription-polymerase chain reaction (RT-PCR) was applied to detected RVA [22], NoV (GI, GII) [23] and As [24]. For RT, the viral RNA was reverse transcribed with PrimeScript $^{\mathrm{TM}}$ RT reagent Kit (Takara Bio Inc, Shiga, Japan). Ad was found using PCR [25] (Table 1).

\section{Enteric protozoan detection}

The genomic DNA of Cryptosporidium spp., G. lamblia and B. hominis was extracted from each stool sample with QIAamp DNA stool mini kit (Qiagen, Hilden, Germany) according to the manufacturers' protocol. The conventional PCR was applied to detect B. hominis [26], the nested PCR was used to detect Cryptosporidium spp. [27] and G. lamblia [28] (Table 1).

\section{Data analysis}

Data analysis was performed by IBM SPSS software (version 19.0 for Windows, Armonk, NY). Odds ratio (OR) and 95\% CIs of categorical variables were calculated using two tailed Chi square or Fisher's exact tests. Quantitative variable was described as mean, median, standard deviation or interquartile range (IQR), among which the median or mean of quantitative variable was compared by rank-sum test, analysis of variance or $t$ test. Logistic regression was performed to find the relationship between diarrhea illness and various enteric pathogens. Single etiology was selected according to bivariate analysis with $p<0.20$. Significant difference was taken as the level of $p<0.05$ with two-tailed test.

\section{Results}

Basic information and clinical symptoms

From July 2014 to June 2015, 420 subjects were recruited for this study, which including 271 diarrhea cases and 149 healthy controls over 5 years. The male-to-female ratio was 0.964 in diarrhea cases and 0.961 in healthy controls $\left(\mathrm{X}^{2}<0.001, p=0.987\right)$, respectively. The median age was 40.0 years in acute diarrhea cases and 41.4 years in nondiarrheal group $(t=0.817, p=0.414)$. The diarrhea cases from urban areas accounted for $67.9 \%$, and the non-diarrhea patients accounted for $66.4 \%\left(\chi^{2}=1.240, p=0.538\right)$. The subjects in the $5-15$ years age group was $64.5 \%$ in diarrhea cases and $63.1 \%$ in healthy controls $\left(x^{2}=0.767\right.$, $p=0.681)$. The most frequent clinical symptom was nausea $(n=91,33.6 \%)$ in diarrhea cases, and other common symptoms included abdominal pain $(n=73,26.9 \%)$, vomiting $(n=58,21.4 \%)$ and fever $(n=22,8.1 \%)$. Mucus stool $(n=173,63.8 \%)$ was the most common stool type in diarrhea cases, followed by watery stool $(n=70,25.8 \%)$ and other types of stool $(n=28,10.3 \%)$ (Table 2$)$. The
Table 2 Basic information and clinical characteristics of 271 acute diarrhea cases and 149 controls over 5 years

\begin{tabular}{|c|c|c|}
\hline Characteristic & $\begin{array}{l}\text { Diarrhea } \\
\text { n (\%) }\end{array}$ & $\begin{array}{l}\text { Control } \\
\text { n (\%) }\end{array}$ \\
\hline $\mathrm{n}$ & 271 & 149 \\
\hline \multicolumn{3}{|l|}{ Age } \\
\hline $5-15$ years & $21(7.7)$ & $9(6.0)$ \\
\hline $15-50$ years & $175(64.6)$ & $94(63.1)$ \\
\hline$\geq 50$ years & $75(27.7)$ & $46(30.9)$ \\
\hline \multicolumn{3}{|l|}{ Sex } \\
\hline Male & $133(49.1)$ & $73(49.0)$ \\
\hline Female & $138(50.9)$ & $76(51.0)$ \\
\hline \multicolumn{3}{|l|}{ Residence } \\
\hline Urban & $184(67.9)$ & $99(66.4)$ \\
\hline Rural-urban fringe zone & $68(25.1)$ & $35(23.5)$ \\
\hline Rural & $19(7.0)$ & $15(10.1)$ \\
\hline \multicolumn{3}{|l|}{ Seasons } \\
\hline Spring (Feb-Apr) & $87(32.1)$ & $32(21.5)$ \\
\hline Summer (May-Jul) & $65(24.0)$ & $42(28.2)$ \\
\hline Autumn (Aug-Oct) & $59(25.5)$ & $45(30.2)$ \\
\hline Winter (Nov-Jan) & $50(18.5)$ & $30(37.5)$ \\
\hline \multicolumn{3}{|l|}{ Symptom } \\
\hline Fever $\left(>37.3^{\circ} \mathrm{C}\right)$ & $23(8.5)$ & - \\
\hline Abdominal pain & $73(26.9)$ & - \\
\hline Nausea & $91(33.6)$ & - \\
\hline Vomiting & $58(21.4)$ & - \\
\hline Dehydration & $3(1.1)$ & - \\
\hline Tenesmus & $5(1.8)$ & - \\
\hline Diarrhea & & - \\
\hline Watery stool & $70(25.8)$ & - \\
\hline Mucus stool & $173(63.8)$ & - \\
\hline Other stool & $28(10.3)$ & - \\
\hline
\end{tabular}

SD represent for standard deviation. Kunming city ( $25^{\circ} 02^{\prime} 20^{\prime \prime} \mathrm{N}, 102^{\circ} 43^{\prime} 05^{\prime \prime}$ E, 1891 m.a.s.l.) has a humid subtropical climate of moderate seasonality characterized by a mild (mean temperature $=11.4^{\circ} \mathrm{C}, \min =8, \max =15$ ) and dry (mean precipitation $=33.4 \mathrm{~mm}, \min =12, \max =89$ ) autumn (Aug-Oct) and winter (Nov-Jan). Spring (Feb-Apr) and summer (May-Jul) are also mild (mean temperature $=23^{\circ} \mathrm{C}, \min =19, \max =29$ ) but wet (mean precipitation $=159.6 \mathrm{~mm}, \min =92, \max =206$ ) seasons. The "-" symbol indicates the information can not be collected

frequency of diarrhea was 5.8 times in acute diarrhea cases within $24 \mathrm{~h}$ (Additional file 2).

\section{The prevalence of enteropathogen in subjects with diarrhea or not}

At least one enteropathogen was isolated from 79 (29.2\%) of 271 acute diarrhea cases and 18 (12.1\%) of 149 healthy controls $\left(x^{2}=15.774, p<0.0001\right)$. The overall prevalence of bacterial pathogen and viral pathogen in diarrhea cases were higher than in healthy controls $\left(x^{2}=11.327\right.$, $p=0.001 ; \chi^{2}=10.795, p=0.001$ respectively. Table 3$)$. At least one intestinal protozoa was found in $4.8 \%(n=13)$ of 
cases and 6.0\% $(n=9)$ of controls $\left(x^{2}=0.299, p=0.584\right)$ (Table 3). In univariate analysis, Details of the enteric pathogens isolates are presented in Table 3, and according to that EAEC, NoV and RVA were more prevalent $\left(\chi^{2}=7.061, p=0.008 ; \chi^{2}=9.160, p=0.002 ; \chi^{2}=7.061\right.$, $p=0.008$ respectively) in diarrhea patients $(7.4,10.0$, $7.4 \%$, respectively) than in healthy controls (1.3, 2.0, $1.3 \%$, respectively, Table 3 ). No statistical difference was observed between acute diarrhea patients and healthy subjects for EPEC, ETEC, NTS, Plesiomonas spp., SaV, As, B. hominis and Cryptosporidium spp. In addition, other enteric parasites were not detected in subjects with and without diarrhea (Table 3). However, the multivariate analysis showed that only RVA was an enteric pathogen associated with diarrhea. But EAEC and NoV GII did not relate with diarrheal illness among individuals over 5 years (Table 3).

In diarrhea cases, DEC $(12.5 \%, n=34)$ was the most common pathogen, followed by NoV GII $(10.0 \%, n=27)$, RVA $(7.0 \%, n=20)$ and B. hominis $(4.8 \%, n=13)$.

\section{Temporal distribution of enteric pathogen in diarrhea} cases

The prevalence of EAEC, EPEC, RVA and B. hominis showed strong seasonal variations (Table 4). The detection rate of EAEC in summer was higher than in winter $(p=0.0045)$, and the prevalence of EPEC in summer was higher than in winter $(p=0.0156)$. RVA was mainly prevalent in autumn and winter $(p=0.0015)$, and the prevalence peak of $B$. hominis was summer $(p<0.0001)$. NoV GII was not statistically different in four seasons $\left(\chi^{2}=3.359, p=0.341\right)$.

\section{Prevalence of enteric pathogens in diarrhea cases} in different age group

Acute diarrhea cases were divided into different age groups, in which 21 (7.7\%), $175(64.6 \%)$ and $75(27.7 \%)$ belong to age groups of $5-15,15-50$ and $\geq 50$ years (Table 5). EPEC infection was the highest in the age group of 5-15 years $(p=0.031)$ (Table 5), but the prevalence of EAEC, RVA, NoV GII and B. hominis were

Table 3 Enteric pathogens in the stool samples with diarrhea cases $(n=271)$ and healthy controls $(n=149)$ in Kunming, China

\begin{tabular}{|c|c|c|c|c|c|c|}
\hline \multirow[t]{2}{*}{ Enteropathogen } & \multirow{2}{*}{$\begin{array}{l}\text { Diarrhea cases } \\
n=271 \\
n(\%)\end{array}$} & \multirow{2}{*}{$\begin{array}{l}\text { Healthy controls } \\
n=149 \\
n(\%)\end{array}$} & \multicolumn{2}{|c|}{ Univariate analysis } & \multicolumn{2}{|c|}{ Multivariate analyses } \\
\hline & & & $p$ value & OR $(95 \% \mathrm{CI})$ & $p$ value & OR (95\% CI) \\
\hline At least one enteropathogen & $79(29.2)$ & $18(12.1)$ & $p<0.0001$ & $3.00(1.71-5.23)$ & - & - \\
\hline At least one enteric bacterial pathogens & $37(13.7)$ & $5(3.4)$ & $p=0.001$ & $4.55(1.75-11.85)$ & - & - \\
\hline DEC & $34(12.5)$ & $5(3.4)$ & $p=0.002$ & $4.13(1.58-10.80)$ & - & - \\
\hline EAEC & $20(7.4)$ & $2(1.3)$ & $p=0.008$ & $5.86(1.35-25.41)$ & $p=0.198$ & $5.95(1.33-26.63)$ \\
\hline EPEC & $15(5.5)$ & $3(2.0)$ & $p=0.088$ & $2.85(0.81-10.01)$ & $p=0.107$ & $2.86(0.80-10.27)$ \\
\hline ETEC & $1(0.4)$ & $0(0.0)$ & - & - & - & - \\
\hline EIEC & $0(0.0)$ & $0(0.0)$ & - & - & - & - \\
\hline EHEC & $0(0.0)$ & $0(0.0)$ & - & - & - & - \\
\hline NTS & $2(0.7)$ & $0(0.0)$ & $p=0.541$ & - & - & - \\
\hline Plesiomonas spp. & $1(0.4)$ & $0(0.0)$ & - & - & - & - \\
\hline Vibrio parahaemolyticus & $0(0.0)$ & $0(0.0)$ & - & - & - & - \\
\hline Vibrio cholera & $0(0.0)$ & $0(0.0)$ & - & - & - & - \\
\hline Aeromonas spp. & $0(0.0)$ & $0(0.0)$ & - & - & - & - \\
\hline Shigella spp. & $0(0.0)$ & $0(0.0)$ & - & - & - & - \\
\hline At least one enteric virus pathogens & $39(14.4)$ & $6(4.0)$ & $p=0.001$ & $4.00(1.66-9.70)$ & - & - \\
\hline NoV GII & $27(10.0)$ & $3(2.0)$ & $p=0.002$ & $5.38(1.60-18.06)$ & $p=0.0794$ & $3.86(0.85-17.48)$ \\
\hline RVA & $20(7.4)$ & $2(1.3)$ & $p=0.008$ & $5.86(1.35-25.41)$ & $p=0.0166$ & $4.50(1.31-15.43)$ \\
\hline NoV Gl & $1(0.4)$ & $0(0.0)$ & - & - & - & - \\
\hline SaV & $1(0.4)$ & $0(0.0)$ & - & - & - & - \\
\hline As & $0(0.0)$ & $1(0.7)$ & $p=0.355$ & - & - & - \\
\hline $\mathrm{Ad}$ & $0(0.0)$ & $0(0.0)$ & - & - & & \\
\hline At least one enteric parasite pathogens & $13(4.8)$ & $9(6.0)$ & $p=0.584$ & $0.78(0.33-1.88)$ & & \\
\hline B. hominis & $13(4.8)$ & $9(6.0)$ & $p=0.584$ & $0.78(0.33-1.88)$ & $p=0.412$ & $0.68(0.27-1.71)$ \\
\hline Cryptosporidium spp. & $1(0.4)$ & $0(0.0)$ & - & - & - & - \\
\hline Giardia lamblia & $0(0.0)$ & $0(0.0)$ & - & - & - & - \\
\hline
\end{tabular}


Table 4 The seasonal characteristics of mainly enteric pathogen isolated from diarrhea cases

\begin{tabular}{|c|c|c|c|c|c|c|}
\hline Enteropathogen & $\begin{array}{l}\text { Spring } \\
\text { (Feb-Apr) } \\
n=87 \\
n(\%)\end{array}$ & $\begin{array}{l}\text { Summer } \\
\text { (May-Jul) } \\
n=65 \\
n(\%)\end{array}$ & $\begin{array}{l}\begin{array}{l}\text { Autumn } \\
\text { (Aug-Oct) }\end{array} \\
\mathrm{n}=69 \\
\mathrm{n}(\%)\end{array}$ & $\begin{array}{l}\text { Winter } \\
\text { (Nov-Jan) } \\
n=50 \\
n(\%)\end{array}$ & $x^{2}$ & $p$ value \\
\hline EAEC & $1(1.2)$ & $9(13.8)$ & $8(11.6)$ & $2(4.0)$ & - & $p=0.0045$ \\
\hline EPEC & $7(8.0)$ & $7(10.8)$ & $1(1.4)$ & $0(0.0)$ & - & $p=0.0156$ \\
\hline RVA & $4(4.6)$ & $0(0.0)$ & $8(11.6)$ & $8(16.0)$ & - & $p=0.0015$ \\
\hline NoV & $5(5.7)$ & $7(10.8)$ & $10(14.5)$ & $5(10.0)$ & 3.359 & $p=0.341$ \\
\hline B. hominis & $0(0.0)$ & $7(10.8)$ & $6(8.7)$ & $0(0.0)$ & - & $p<0.0001$ \\
\hline
\end{tabular}

Including the co-infection of any enteric pathogens in diarrhea cases. The "-" symbol indicates that data be calculated with Fisher-exact tests

not statistical difference among these three age groups (Table 5), respectively.

\section{Co-infection of enteric pathogen in diarrhea cases and healthy cases}

In this study, the prevalence of co-infection with more than one enteric pathogens was higher than in healthy controls (Table 6, $p=0.0059$, OR $=6.17,95 \%$ CI $1.43-$ 26.71). In various co-infection cases, the co-infection with two enteric pathogens was more commonly detected in diarrhea patients than non-diarrhea subjects (Table 6, $p=0.0079$, OR $=5.86,95 \%$ CI 1.35-25.41). However, the prevalence of co-infection with more than three enteric pathogens in patents was as much as in healthy controls.

20 diarrhea cases of co-infections with two pathogens was identified, whereby two pathogens were identified, the prominent prevalence was virus-virus $(45.0 \%, 9 / 20)$, followed by bacteria-virus $(25.0 \%, 5 / 20)$ and bacteria-protozoan $(15.0 \%, 3 / 20)$, and the other comprised co-infection was less common in diarrhea cases. The highest prevalence of co-infection in diarrhea cases was RVA-NoV GII (3.0\%, $n=8)$, followed by DEC-NoV GII $(1.5 \%, n=4)$, DECRVA $(1.1 \%, n=3)$ and DEC-B. hominis $(1.1 \%, n=3)$. The prevalence of other co-infection between two pathogens was less than $1.0 \%$ in acute diarrhea cases (Table 6).

\section{Discussion}

Since most studies had focused on diarrheal illness in children under 5 years $[6,11]$, little is known about the prevalence of acute diarrhea caused by enteric pathogens among person over 5 years. This study was the first of its kind conducted to determine the enteropathogens of acute diarrheal disease in Yunnan Province, China, and a series of pathogens involving bacteria, viruses and parasites were examined with a combination of conventional and molecular diagnostic techniques.

The detection rate of at least one enteric pathogen was significantly higher in diarrhea cases than in healthy controls, which showed a wide range of pathogens involving bacteria, and similar results have also been obtained from other countries $[29,30]$. Although bacteria and parasites

Table 5 Prevalence of enteric pathogens in diarrhea cases in different age groups

\begin{tabular}{|c|c|c|c|c|c|c|}
\hline Enteropathogen & $\begin{array}{l}\text { Total } \\
n=271 \\
n(\%)\end{array}$ & $\begin{array}{l}5-15 \text { years } \\
n=21 \\
n(\%)\end{array}$ & $\begin{array}{l}15-50 \text { years } \\
n=175 \\
n(\%)\end{array}$ & $\begin{array}{l}\geq 50 \text { years } \\
n=75 \\
n(\%)\end{array}$ & $x^{2}$ & $p$ value \\
\hline At least one enteropathogens & $79(29.2)$ & $9(42.9)$ & $52(29.7)$ & $18(24.0)$ & 2.90 & $p=0.234$ \\
\hline At least one bacterium & $37(13.7)$ & $5(23.8)$ & $27(15.4)$ & $5(6.7)$ & 5.41 & $p=0.0668$ \\
\hline At least one virus & $39(14.4)$ & $4(19.0)$ & $23(13.1)$ & $12(16.0)$ & 0.748 & $p=0.688$ \\
\hline At least one parasite & $13(4.8)$ & $1(4.8)$ & $10(5.7)$ & $2(2.7)$ & - & $p=0.654$ \\
\hline EAEC & $20(7.4)$ & $1(4.8)$ & $16(9.1)$ & $3(4.0)$ & 2.56 & $p=0.323$ \\
\hline EPEC & $15(5.5)$ & $4(19.0)$ & $9(5.0)$ & $2(2.7)$ & - & $p=0.031$ \\
\hline NoV & $27(10.0)$ & $4(19.0)$ & $15(8.6)$ & $8(10.7)$ & 2.35 & $p=0.309$ \\
\hline RVA & $20(7.4)$ & $2(9.5)$ & $13(7.4)$ & $5(6.7)$ & 0.198 & $p=0.906$ \\
\hline B. hominis & $13(4.8)$ & $1(4.8)$ & $10(5.7)$ & $2(2.7)$ & - & $p=0.654$ \\
\hline
\end{tabular}

Including the co-infection of any enteric pathogens in diarrhea cases. The" "-" symbol indicates that data be calculated with Fisher-exact tests 
Table 6 The co-infection of enteric pathogens detected in diarrhea cases and healthy controls

\begin{tabular}{|c|c|c|c|c|}
\hline Co-infections of enteric pathogens & $\begin{array}{l}\text { Diarrhea cases } \\
\mathrm{n}=271 \\
\mathrm{n}(\%)\end{array}$ & $\begin{array}{l}\text { Healthy controls } \\
n=149 \\
n(\%)\end{array}$ & $p$ value & OR $(95 \% \mathrm{Cl})$ \\
\hline Any two any enteric pathogens & $20(7.4)$ & $2(1.3)$ & $p=0.0079$ & $5.86(1.35-25.41)$ \\
\hline Virus-virus & $9(3.3)$ & $0(0.0)$ & $p=0.0298$ & - \\
\hline RVA-NoV GII & $8(3.0)$ & $0(0.0)$ & $p=0.0549$ & - \\
\hline Bacteria-virus & $5(1.8)$ & $0(0.0)$ & $p=0.166$ & - \\
\hline DEC-NoV GII & $4(1.5)$ & $0(0.0)$ & $p=0.302$ & - \\
\hline DEC-RVA & $3(1.1)$ & $0(0.0)$ & $p=0.556$ & - \\
\hline Bacteria-protozoan & $3(1.1)$ & $2(1.3)$ & $p=0.999$ & $0.83(0.14-5.00)$ \\
\hline DEC-B. hominis & $3(1.1)$ & $2(1.3)$ & $p=0.999$ & $0.83(0.14-5.00)$ \\
\hline Any three enteric pathogens & $1(0.4)$ & $0(0.0)$ & $p=0.999$ & - \\
\hline DEC-RVA-Cryptosporidium spp. & $1(0.4)$ & $0(0.0)$ & $p=0.999$ & - \\
\hline Total & $21(7.7)$ & $2(1.3)$ & $p=0.0059$ & $6.17(1.43-26.71)$ \\
\hline
\end{tabular}

Only co-infections with two pathogens found in at least $1 \%$ of diarrhea cases have been shown. The "-" symbol indicates the data can not be calculated

were the prominent enteropathogen in acute diarrheal cases aged more than 5 years in some developing countries [31], to our surprise, viral pathogens (RVA and NoV) were the most common pathogen in present study.

DEC were detected with a PCR method in stool sample from the patients and non-diarrheal controls, and the result showed that DEC wasn't the causative agent of diarrhea in individuals over 5 years, and similar conclusions were shown in another study [32]. However, the authors of the other study argued that DEC was one of important enteric pathogen causing acute diarrhea [33]. The detection rate of DEC in present study was lower than that presented in other study [32], but it was higher than that presented in other region of China [11]. The prevalence of DEC varies greatly in different regions due to the detection method [11], behavior habits, geography and environmental hygiene among different areas [34]. Although the molecular biology techniques (e.g. PCR and Real-time PCR) are useful for detecting DEC, PCR was not used widely in medical facilities because of constraints in many developing countries, including the poor laboratory conditions, limited funds and low detection capacities of staff [16]. Hence, DEC was not a pathogen that was routinely detected in clinical laboratories especially in low and middle income countries [35, 36]. The DEC was detected in many studies with the traditional serum agglutination method which has low sensitivity and specificity. Therefore, the prevalence of DEC was underestimated and the pathogenic spectrum of acute diarrheal illness was not accurately described [4]. It was accurately described to detect DEC by PCR with high sensitivity and specificity due to the following reasons [31]: Firstly, the clinical symptom of diarrhea caused by different DEC subtypes and other enteropathogens cannot be distinguished easily. Secondly, DEC is widely prevalent in food and environment, and the modern tourism and trade had accelerated the spread of DEC. The modern detection method (e.g. PCR) can improve the sensitivity and specificity for detecting DEC in stool samples in order to accurately assess the burden of DEC in cases [4, 31]. In addition, the modern method has advantages in saving diagnosis time and reducing workload of finding DEC in diarrhea cases. Especially, it is more accurate to identify the various DEC subtypes, and it can be completed more quickly and more accurately.

EAEC is also the leading cause of diarrhea in children, adult and HIV-positive patients worldwide [37, 38]. In addition, EAEC was one of major causes of diarrhea outbreak in some developed countries (e.g. Europe, the UK and Japan) [31, 38]. EAEC was not the important bacterial pathogen associated diarrhea in individuals over 5 years in present study, and similar conclusion was obtained from other study [32]. However another study showed that EAEC was associated with diarrheal disease [33]. Further studies found that the concentration with $10^{10} \mathrm{CFU}$ of serotype 042 EAEC strain can lead to diarrhea, but other serotype of EAEC strain cannot cause diarrhea in children and adults [37, 38]. It can be deducted that the genotype is likely to be an important factor in determining pathogenicity. The detection rate of EAEC in this study was as high as $7.4 \%$, which was similar to the other study [33]. However the prevalence of EAEC was still lower than in many developing countries [37]. In the present study, EPEC was also not associated with diarrhea disease, similar to other study [31]. Further mechanism research might be conducted to explore the pathogenicity and infectivity at a genetic level. 
Adults suffering diarrhea rarely visit a medical institution, unless they have acute serious or persistent diarrhea. The study suggests that although many enteric pathogens were detected from diarrhea patients over 5 years old, only RVA was significantly related with diarrheal illness in individuals over 5 years old. This study provides further evidence that RVA is a cause of acute adult diarrhea in China, but other study show that RVA was not an etiological agent with diarrhea [32]. The frequency of RVA infection (7.4\%) was close to other study (9.6\%) [39], but was higher than in the study (2.6\%) conducted in adolescents or adults (10-89 years) in Italy [40].

NoV GII is one of major pathogens which can lead sporadic and outbreak acute diarrhea cases across all age groups worldwide [41]. The present study showed that NoV GII was the second most common enteropathogen in diarrhea cases. The high prevalence of NoV GII in individuals might be attributed to frequent social activities, and NoV GII is one of the most important food borne pathogen and exists widely in foods (such as shellfish, vegetables and water, et al.). These foods contaminated with NoV GII were primary reasons to lead sporadic and outbreak acute diarrhea [42-45]. The detection rate of NoV GII in our study was lower than that of in other study [46, 47]. The reason might be that seafood (e.g. shellfish) was not easily obtained and was not a conventional food in inland of China, including Kunming city.

Blastocystis hominis was found to be the most common protozoan in gastrointestinal tract of human and animals. It was widespread in natural world [48] and was highly prevalent in immunodeficiency patients [49]. Blastocystis hominis was not a pathogenic agent in present study, but other studies showed that $B$. hominis was a diarrhea-associated pathogen $[50,51]$. Blastocystis hominis had high prevalence in healthy controls in present study implied that $B$. hominis was carried in health individual, which was a common phenomenon [50]. Whether $B$. hominis was one of pathogenic pathogen is need to explore the pathogenicity of different subtypes and mechanism. Cryptosporidium spp. and G. lamblia are leading cause of acute and chronic diarrhea in the tropics regions and some developing counties [52], but Cryptosporidium spp. had low prevalence and no one G. lamblia was detected in cases and healthy controls in present study, which indicating that these two kinds of intestinal protozoa were not serious disease burden and intimidate to individuals over 5 years old. This low prevalence of two protozoa might be due to epidemic characteristics of enteric parasites. Our research field was selected in urban with perfective municipal facilities of sewage treatment system, chlorine disinfection water, as well as, the population with high living level and health habits, so that the detection rate of enteric protozoa was very low, and the same results was showed in other studies in China [5, 17].

The co-infection was not neglected in diarrhea cases (7.7\%) in this study, although other studies found that co-infection was high prevalent in sick individuals (13.0, $35.0,25.0 \%$, respectively) $[12,13,53]$. The co-infection leads to that individuals with greater levels of morbidity and mortality, making persons more vulnerable to species, for instance, the co-infection of RVA and other enteric pathogen can aggravate diarrheal symptom [14, 54]. In addition, the co-infection adds the difficulty to accurately determine etiological role of the enteric pathogen. Although co-infection by multiple groups of pathogens is the norm rather than the exception in nature, most research on the effect of pathogens on their hosts has been largely based on a single or few pathogen species [15]. Understanding the causes and consequences of co-infection among enteric pathogens remains one of the major challenges. Nevertheless, there is an increasing interest to move from the 'diarrheal disease-one enteric pathogen' perspective to a more holistic view of hosts as ecosystems of diarrhea illness [6], partially motivated by the health impact of co-occurring infections. In fact, in such complex 'host-enteric pathogen ecosystems' a variety of both direct and indirect interactions between enteric pathogens, their hosts and the circumstances must be taken into account [55].

\section{Limitations of this study}

It was indentified several limitations in this study. Firstly, the study was conducted in an urban region that probably shows a poor representation of the potential enteric pathogen. Secondly, the diarrhea cases were selected from outpatients and hospitalized cases. But the patients who did not to seek medical advice were not recruited. Thirdly, helminthes and some intestinal bacteria were not detected in this study. Fourthly, the percentage of diarrheal patients who have taken antibiotics before the admission was not known, which may influence the detection rate of bacterial pathogens. In addition, enteric protozoa were not detected with microscopy, and the concentration of DNA in $1 \mu \mathrm{L}$ can be different and therefore, the outcome of PCR might not be comparable [56]. Therefore, further research involved diarrhea case from urban, rural, outpatient and hospitalized might be done to evaluate the burden of diarrhea disease and assess the association between diarrhea and specific enteric pathogen. Match case-control study will be a good choice, and quantitate the DNA by nanodrop or something else and then loaded equal amount of DNA (e.g. $1 \mathrm{ng}$ ) for every PCR reaction will be have high reliability for entire project. 


\section{Conclusions}

Although it appears clear that RVA has impact on diarrhea illness, it was ignored in individuals over 5 years old. The prevalence of DEC was high in diarrhea cases, but it would be largely neglected due to lack of access to good quality diagnostic tests, which suggests that enhance laboratory capacities are urgently need in order to implement diarrhea surveillance programs. The coinfection was high prevalent in diarrhea cases, which will respond to better medical and public health interventions of diarrhea disease. In view of the diarrhea cases detected in urban region of Kunming city, Yunnan Province, which have effluent sewerage system, good sanitary condition and clean drinking water, it is concluded that food pollution might be the leading cause of acute gastroenteritis.

\section{Additional file}

Additional file 1: The detection process of enteric pathogens applied in the study.

Additional file 2: The information of all subjects recruited in the study.

\begin{abstract}
Abbreviations
Ad: adenovirus; As: astrovirus; AWP: alkaline peptone water; B. hominis: Blastocystis hominis; Cl: confidence interval; CFU: colony-forming unit-megakaryocyte; DEC: diarrheagenic E. coli; EAEC: enteroaggregative E. coli; EHEC: enterohemorrhagic E. coli; EIEC: enteroinvasive E. coli; EPEC: enteropathogenic E. coli; ETEC: enterotoxigenic E. Coli; G. lamblia: Giardia lamblia; MAC: macConkey agar; NoV: norovirus; NTS: non-typhoidal salmonella; OR: odd ratios; qPCR: quantitative PCR; RT-PCR: reverse transcription polymerase chain reaction; RVA: rotavirus A group; SaV: sapovirus; SD: standard deviation; SS: Salmonella-Shigella; TCBS: thiosulfate-citrate-bile salts-sucrose; WHO: World Health Organization; XLD: xylose, lysine and deoxycholate agar.
\end{abstract}

\section{Authors' contributions}

$S X-Z$ and $E S$ performed the statistical analysis and drafted the manuscript. LG-T, JX-C, WH and XN-Z conceived and designed the study, CL-Y, LA, WP-G, $X Z, S Z-L, S L, Z S-D$ and JH-C conducted the dates collected and pathogens detected, PY edited the English. All authors read and approved the final manuscript.

\section{Author details \\ ${ }^{1}$ National Institute of Parasitic Diseases, Chinese Center for Disease Control and Prevention, Shanghai 200025, People's Republic of China. ${ }^{2}$ Key Labora- tory for Parasitology and Vector Biology, $\mathrm{MOH}$ of China, WHO Collaborat- ing Center for Tropical Diseases, National Center for International Research on Tropical Diseases, Shanghai 20025, People's Republic of China. ${ }^{3}$ Yunnan Provincial Center for Disease Control and Prevention, Kunming 650022, People's Republic of China. ${ }^{4}$ Center for Environmental and Marine Studies (CESAM), Departamento de Biología, Universidade de Aveiro, Aveiro, Portugal. ${ }^{5}$ Servei d’Ecopatologia de Fauna Salvatge (SEFaS), Departament de Medicina i Cirurgia Animals, Universitat Autònoma de Barcelona (UAB), Bellaterra, Spain. ${ }^{6}$ Department of parasitology, College of Medicine, Soochow University, Suzhou 215123, People's Republic of China.}

\section{Acknowledgements}

None.

\section{Competing interests}

The authors declare that they have no competing interests.

\section{Availability of data and materials}

Data of the study can be available upon request from the corresponding author $(\mathrm{XN}-\mathrm{Z})$

\section{Ethics approval and consent to participate}

The study was approved by the ethical review committee of the National Institute of Parasitic Diseases, Chinese Center for Disease Control and Prevention. Informed verbal or written consent was obtained from the subject or their parents/guardians before collecting the stool samples.

\section{Funding}

Development of PCR to detect virus, G. lamblia was supported by the National Science and Technology Major Project (Grant number: 2008ZX10004-011); Development of PCR to find Cryptosporidium spp. was supported by National Science and Technology Major Project (2012ZX10004-220). The B. hominis identified was supported from National Natural Science Foundation of China (Grant number: 81473022). The field epidemiological investigation was supported by Chinese Special Program for Scientific Research of Public Health (No. 201502021). The bacterial pathogens identified was supported by The Fourth Round Three Year Action Plan Public Health of Shanghai city (GWIV-29). The data analysis was supported from the fund of the postdoctoral programme of the Fundação para a Ciência ea Tecnologia the Fundação para a Ciência ea Tecnologia, Portugal (SFRH/BPD/96637/2013).

Received: 19 July 2016 Accepted: 5 November 2016

Published online: 16 November 2016

\section{References}

1. Lozano R, Naghavi M, Foreman K, Lim S, Shibuya K, Aboyans V, Abraham J, Adair T, Aggarwal R, Ahn SY, et al. Global and regional mortality from 235 causes of death for 20 age groups in 1990 and 2010: a systematic analysis for the global burden of disease study 2010. Lancet. 2012;380(9859):2095-128. doi:10.1016/S0140-6736(12)61728-0.

2. Walker CL, Rudan I, Liu L, Nair H, Theodoratou E, Bhutta ZA, O'Brien KL, Campbell H, Black RE. Global burden of childhood pneumonia and diarrhoea. Lancet. 2013;381(9875):1405-16. doi:10.1016/S0140-6736(13)60222-6.

3. Platts-Mills JA, Babji S, Bodhidatta L, Gratz J, Haque R, Havt A, McCormick BJ, McGrath M, Olortegui MP, Samie A, et al. Pathogen-specific burdens of community diarrhoea in developing countries: a multisite birth cohort study (MAL-ED). Lancet Glob Health. 2015;3(9):e564-75. doi:10.1016/ S2214-109X(15)00151-5.

4. Liu J, Kabir F, Manneh J, Lertsethtakarn P, Begum S, Gratz J, Becker SM, Operario DJ, Taniuchi M, Janaki L, et al. Development and assessment of molecular diagnostic tests for 15 enteropathogens causing childhood diarrhoea: a multicentre study. Lancet Infect Dis. 2014;14(8):716-24. doi:10.1016/S1473-3099(14)70808-4.

5. Hao R, Li P, Wang Y, Qiu S, Wang L, Li Z, Xie J, Wu Z, Lin R, Liu N, et al. Diversity of pathogens responsible for acute diarrheal disease in China. Clin Infect Dis. 2013;57(12):1788-90. doi:10.1093/cid/cit572.

6. Zhang SX, Zhou YM, Xu W, Tian LG, Chen JX, Chen SH, Dang ZS, Gu WP, Yin JW, Serrano E, et al. Impact of co-infections with enteric pathogens on children suffering from acute diarrhea in southwest China. Infect Dis Poverty. 2016;5(1):64. doi:10.1186/s40249-016-0157-2.

7. Nic Fhogartaigh C, Dance DAB. Bacterial gastroenteritis. Medicine. 2013;41(12):693-9.

8. Fischer WC, Sack D, Black RE. Etiology of diarrhea in older children, adolescents and adults: a systematic review. PLoS Negl Trop Dis. 2010;4(8):e768. doi:10.1371/journal.pntd.0000768.

9. Duan ZJ, Liu N, Yang SH, Zhang J, Sun LW, Tang JY, Jin Y, Du ZQ, Xu J, Wu $\mathrm{QB}$, et al. Hospital-based surveillance of rotavirus diarrhea in the People's Republic of China, August 2003-July 2007. J Infect Dis. 2009;200(Suppl 1):S167-73. doi:10.1086/605039.

10. Tang MB, Chen CH, Chen SC, Chou YC, Yu CP. Epidemiological and molecular analysis of human norovirus infections in Taiwan during 2011 and 2012. BMC Infect Dis. 2013;13:338. doi:10.1186/1471-2334-13-338.

11. Qu M, Deng Y, Zhang X, Liu G, Huang Y, Lin C, Li J, Yan H, Li X, Jia L, et al. Etiology of acute diarrhea due to enteropathogenic bacteria in Beijing, China. J Infect. 2012;65(3):214-22. doi:10.1016/j.jinf.2012.04.010. 
12. Nimri LF, Elnasser Z, Batchoun R. Polymicrobial infections in children with diarrhoea in a rural area of Jordan. FEMS Immunol Med Microbiol. 2004;42(2):255-9.

13. Vu NT, Le Van P, Le Huy C, Nguyen GK, Weintraub A. Etiology and epidemiology of diarrhea in children in Hanoi, Vietnam. Int J Infect Dis. 2006;10(4):298-308.

14. Bhavnani D, Goldstick JE, Cevallos W, Trueba G, Eisenberg JNS. Synergistic effects between rotavirus and coinfecting pathogens on diarrheal disease: evidence from a community-based study in Northwestern Ecuador. Am J Epidemiol. 2012;176(5):387-95. doi:10.1093/aje/kws220.

15. Serrano E, Millan J. What is the price of neglecting parasite groups when assessing the cost of co-infection? Epidemiol Infect. 2014;142(7):1533-40. doi:10.1017/S0950268813002100.

16. Zhang Y, Zhao Y, Ding K, Wang X, Chen X, Liu Y, Chen Y. Analysis of bacterial pathogens causing acute diarrhea on the basis of sentinel surveillance in Shanghai, China, 2006-2011. Jpn J Infect Dis. 2014;67(4):264-8.

17. Yu J, Jing H, Lai S, Xu W, Li M, Wu J, Liu W, Yuan Z, Chen Y, Zhao S, et al. Etiology of diarrhea among children under the age five in China: results from a five-year surveillance. J Infect. 2015;71(1):19-27. doi:10.1016/j.jinf.2015.03.001.

18. Liu N, Xu Z, Li D, Zhang Q, Wang H, Duan ZJ. Update on the disease burden and circulating strains of rotavirus in China: a systematic review and metaanalysis. Vaccine. 2014;32(35):4369-75. doi:10.1016/j.vaccine.2014.06.018.

19. The World Health Organization. http://www.who.int/mediacentre/ factsheets/fs330/en/. Accessed Apr 2013.

20. Deer DM, Lampel KA. Development of a multiplex real-time PCR assay with internal amplification control for the detection of Shigella species and enteroinvasive Escherichia coli. J Food Prot. 2010;73(9):1618-25.

21. Hidaka A, Hokyo T, Arikawa K, Fujihara S, Ogasawara J, Hase A, HaraKudo Y, Nishikawa Y. Multiplex real-time PCR for exhaustive detection of diarrhoeagenic Escherichia coli. J Appl Microbiol. 2009;106(2):410-20. doi:10.1111/j.1365-2672.2008.04043.x.

22. Iturriza GM, Wong C, Blome S, Desselberger U, Gray J. Molecular characterization of VP6 genes of human rotavirus isolates: correlation of genogroups with subgroups and evidence of independent segregation. J Virol. 2002;76(13):6596-601.

23. Zintz C, Bok K, Parada E, Barnes-Eley M, Berke T, Staat MA, Azimi P, Jiang $X$, Matson DO. Prevalence and genetic characterization of caliciviruses among children hospitalized for acute gastroenteritis in the United States. Infect Genet Evol. 2005;5(3):281-90

24. Yan H, Yagyu F, Okitsu S, Nishio O, Ushijima H. Detection of norovirus (G) GII), sapovirus and astrovirus in fecal samples using reverse transcription single-round multiplex PCR. J Virol Methods. 2003;114(1):37-44.

25. Khamrin P, Okame M, Thongprachum A, Nantachit N, Nishimura S, Okitsu S, Maneekarn N, Ushijima H. A single-tube multiplex PCR for rapid detection in feces of 10 viruses causing diarrhea. J Virol Methods. 2011;173(2):390-3. doi:10.1016/j.jviromet.2011.02.012.

26. Menounos PG, Spanakos G, Tegos N, Vassalos CM, Papadopoulou C, Vakalis NC. Direct detection of Blastocystis sp. in human faecal samples and subtype assignment using single strand conformational polymorphism and sequencing. Mol Cell Probes. 2008;22(1):24-9.

27. Liu H, Shen Y, Yin J, Yuan Z, Jiang Y, Xu Y, Pan W, Hu Y, Cao J. Prevalence and genetic characterization of Cryptosporidium, Enterocytozoon, Giardia and Cyclospora in diarrheal outpatients in China. BMC Infect Dis. 2014;14:25. doi:10.1186/1471-2334-14-25.

28. Sulaiman IM, Fayer R, Bern C, Gilman RH, Trout JM, Schantz PM, Das P, Lal AA, Xiao L. Triosephosphate isomerase gene characterization and potential zoonotic transmission of Giardia duodenalis. Emerg Infect Dis. 2003;9(11):1444-52.

29. Albert MJ, Faruque AS, Faruque SM, Sack RB, Mahalanabis D. Case-control study of enteropathogens associated with childhood diarrhea in Dhaka, Bangladesh. J Clin Microbiol. 1999;37(11):3458-64.

30. Randremanana R, Randrianirina F, Gousseff M, Dubois N, Razafindratsimandresy R, Hariniana ER, Garin B, Randriamanantena A, Rakotonirina HC, Ramparany L, et al. Case-control study of the etiology of infant diarrheal disease in 14 districts in Madagascar. PLoS ONE. 2012;7(9):e44533. doi:10.1371/journal.pone.0044533.

31. Thompson CN, Phan MV, Hoang NV, Minh PV, Vinh NT, Thuy CT, Nga TT, Rabaa MA, Duy PT, Dung TT, et al. A prospective multi-center observational study of children hospitalized with diarrhea in Ho Chi Minh City, Vietnam. Am J Trop Med Hyg. 2015;92(5):1045-52. doi:10.4269/ ajtmh.14-0655.
32. Al-Gallas N, Bahri O, Bouratbeen A, Ben Haasen A, Ben Aissa R. Etiology of acute diarrhea in children and adults in Tunis, Tunisia, with emphasis on diarrheagenic Escherichia coli: prevalence, phenotyping, and molecular epidemiology. Am J Trop Med Hyg. 2007;77(3):571-82.

33. Bruijnesteijn VCL, Dullaert-de BM, Ruijs GJ, van der Reijden WA, van der Zanden AG, Weel JF, Schuurs TA. Case-control comparison of bacterial and protozoan microorganisms associated with gastroenteritis: application of molecular detection. Clin Microbiol Infect. 2015;21(6):592-e9-19. doi:10.1016/j.cmi.2015.02.007.

34. Okeke IN. Diarrheagenic Escherichia coli in sub-Saharan Africa: status, uncertainties and necessities. J Infect Dev Ctries. 2009;3(11):817-42.

35. Gerner-Smidt P, Jensen C, Olsen KE, Scheutz F, Molbak K, Olesen B. Diarrheagenic potential of Escherichia coli in children in a developed country. J Clin Microbiol. 2003;41(12):5836.

36. Estrada-Garcia T, Cerna JF, Paheco-Gil L, Velazquez RF, Ochoa TJ, Torres J, DuPont HL. Drug-resistant diarrheogenic Escherichia coli, Mexico. Emerg Infect Dis. 2005;11(8):1306-8.

37. Huang DB, Mohanty A, DuPont HL, Okhuysen PC, Chiang T. A review of an emerging enteric pathogen: enteroaggregative Escherichia coli. J Med Microbiol. 2006;55(Pt 10):1303-11.

38. Hebbelstrup JB, Olsen KE, Struve C, Krogfelt KA, Petersen AM. Epidemiology and clinical manifestations of enteroaggregative Escherichia coli. Clin Microbiol Rev. 2014;27(3):614-30. doi:10.1128/CMR.00112-13.

39. Luchs A, Cilli A, Morillo SG, de Cassia CCR, Do CSTT. Rotavirus in adults, Brazil, 2004-2011: g2P[4] dominance and potential impact on vaccination. Braz J Infect Dis. 2014;18(1):53-9. doi:10.1016/j.bjid.2013.05.010.

40. Ianiro G, Delogu R, Bonomo P, Fiore L, Ruggeri FM. Molecular analysis of group $A$ rotaviruses detected in adults and adolescents with severe acute gastroenteritis in Italy in 2012. J Med Virol. 2014;86(6):1073-82. doi:10.1002/jmv.23871.

41. Ahmed SM, Hall AJ, Robinson AE, Verhoef L, Premkumar P, Parashar UD, Koopmans M, Lopman BA. Global prevalence of norovirus in cases of gastroenteritis: a systematic review and meta-analysis. Lancet Infect Dis. 2014;14(8):725-30. doi:10.1016/S1473-3099(14)70767-4.

42. Campos CJ, Lees DN. Environmental transmission of human noroviruses in shellfish waters. Appl Environ Microbiol. 2014;80(12):3552-61.

43. Hall AJ, Eisenbart VG, Etingue AL, Gould LH, Lopman BA, Parashar UD. Epidemiology of foodborne norovirus outbreaks, United States, 2001-2008. Emerg Infect Dis. 2012;18(10):1566-73. doi:10.3201/ eid1810.120833.

44. Crim SM, Iwamoto M, Huang JY, Griffin PM, Gilliss D, Cronquist AB, Cartter M, Tobin-D'Angelo M, Blythe D, Smith K, et al. Incidence and trends of infection with pathogens transmitted commonly through food-foodborne diseases active surveillance network, 10 US sites, 2006-2013. MMWR Morb Mortal Wkly Rep. 2014;63(15):328-32.

45. Huang J, Xu X, Weng Q, Hong H, Guo Z, He S, Niu J. Serial foodborne norovirus outbreaks associated with multiple genotypes. PLOS ONE. 2013;8(5):e63327. doi:10.1371/journal.pone.0063327.

46. Tian G, Jin M, Li H, Li Q, Wang J, Duan ZJ. Clinical characteristics and genetic diversity of noroviruses in adults with acute gastroenteritis in Beijing, China in 2008-2009. J Med Virol. 2014;86(7):1235-42. doi:10.1002/ jmv.23802.

47. Jin M, Chen J, Zhang XH, Zhang M, Li HY, Cheng WX, Liu N, Tan M, Jiang T, Duan ZJ. Genetic diversity of noroviruses in Chinese adults: potential recombination hotspots and GII-4/Den Haag-specific mutations at a putative epitope. Infect Genet Evol. 2011;11(7):1716-26. doi:10.1016/j. meegid.2011.07.005.

48. Thathaisong $U$, Worapong J, Mungthin M, Tan-Ariya P, Viputtigul K, Sudatis A, Noonai A, Leelayoova S. Blastocystis isolates from a pig and a horse are closely related to Blastocystis hominis. J Clin Microbiol. 2003;41(3):967-75.

49. Tian LG, Chen JX, Wang TP, Cheng GJ, Steinmann P, Wang FF, Cai YC, Yin XM, Guo J, Zhou L, et al. Co-infection of HIV and intestinal parasites in rural area of China. Parasites Vectors. 2012;5:36. doi:10.1186/1756-3305-5-36.

50. Wang KX, Li CP, Wang J, Cui YB. Epidemiological survey of Blastocystis hominis in Huainan City, Anhui Province, China. World J Gastroenterol. 2002;8(5):928-32.

51. Clark CG, van der Giezen M, Alfellani MA, Stensvold CR. Recent developments in Blastocystis research. Adv Parasitol. 2013;82:1-32. doi:10.1016/ B978-0-12-407706-5.00001-0. 
52. Kotloff KL, Nataro JP, Blackwelder WC, Nasrin D, Farag TH, Panchalingam S, Wu Y, Sow SO, Sur D, Breiman RF, et al. Burden and aetiology of diarrhoeal disease in infants and young children in developing countries (the Global Enteric Multicenter Study, GEMS): a prospective, case-control study. Lancet. 2013;382(9888):209-22. doi:10.1016/S0140-6736(13)60844-2.

53. Li LL, Liu N, Humphries EM, Yu JM, Li S, Lindsay BR, Stine OC, Duan ZJ. Aetiology of diarrhoeal disease and evaluation of viral-bacterial coinfection in children under 5 years old in China: a matched case-control study. Clin Microbiol Infect. 2016;22(4):381.e9-16. doi:10.1016/j.cmi.2015.12.018.

54. Valentini D, Vittucci AC, Grandin A, Tozzi AE, Russo C, Onori M, Menichella D, Bartuli A, Villani A. Coinfection in acute gastroenteritis predicts a more severe clinical course in children. Eur J Clin Microbiol Infect Dis. 2013;32(7):909-15. doi:10.1007/s10096-013-1825-9.
55. Seabloom EW, Borer ET, Gross K, Kendig AE, Lacroix C, Mitchell CE, Mordecai EA, Power AG. The community ecology of pathogens: coinfection, coexistence and community composition. Ecol Lett. 2015;18(4):401-15. doi:10.1111/ele.12418.

56. Zhang SX, Li L, Yin JW, Jin M, Kong XY, Pang LL, Zhou YK, Tian LG, Chen $J X$, Zhou XN. Emergence of human caliciviruses among diarrhea cases in southwest China. BMC Infect Dis. 2016;16(1):511. doi:10.1186/ s12879-016-1831-5

\section{Submit your next manuscript to BioMed Central and we will help you at every step:}

- We accept pre-submission inquiries

- Our selector tool helps you to find the most relevant journal

- We provide round the clock customer support

- Convenient online submission

- Thorough peer review

- Inclusion in PubMed and all major indexing services

- Maximum visibility for your research

Submit your manuscript at www.biomedcentral com/submit 